\title{
Car Parking Distance Controller Using Ultrasonic Sensors Based On Arduino Uno
}

\author{
Jenli Susilo $^{1}$, Anita Febriani ${ }^{2}$, Uci Rahmalisa ${ }^{3}$, Yuda Irawan ${ }^{4 *}$ \\ 1,2 Department of Computer Science, STMIK Hang Tuah Pekanbaru, Pekanbaru, Indonesia \\ ${ }^{3,4}$ Department of Information System, STMIK Hang Tuah Pekanbaru, Pekanbaru, Indonesia \\ Email: ${ }^{1}$ jenlydoang@gmail.com, ${ }^{2}$ nitasuheri@gmail.com, ${ }^{3}$ ucirahmalisa89@ gmail.com, \\ 4yudairawan89@gmail.com \\ *Corresponding Author
}

\begin{abstract}
The design of a car parking sensor is done because there are some problems such as the absence of parking attendants from 18:00 to 06:00 and the lack of parking attendants so the researchers took the title of arduino uno-based car parking distance controller by using ultrasonic sensors in this study using 3 main components, namely Arduino UNO, Arduino MP3 Shield and Ultrasonic HC-SR04. Arduino Shield MP3 is a module that is used to play sound. MP3 which can give voice commands that have been programmed before using Arduino IDE and combined with Ultrasonic HC-SR04 components in the calculation of the distance to the object. The distance $(\mathrm{cm})$ obtained as input is then processed and then combined with the Arduino Shield MP3, then at a predetermined distance will output a predetermined voice command. Then the method used is the prototype method which starts from designing, writing the system, implementing it with the aim of making a prototype of a car parking sensor and testing it with a prototype. Conclusion testing the car sensor sensor car makes it easy for car drivers to park the car.
\end{abstract}

Keywords- Arduino Uno, Sensor Ultrasonic HC- SR04, Parking, Car, MP3 Shield Arduino

\section{INTRODUCTION}

The current technological developments provide facilities for human life, one of which is in the field of transportation. We can find technological developments in the field of transportation, including parking security systems for car was studied by nasution [1]. Previously, parking in a place, be it a building, parking lot for supermarkets, malls, at home and others, required a lot of time and energy was studied by sahfutri [2]. Parking users have difficulty adjusting the position of the vehicle so that the car can be parked properly was studied by wu [3]. In fact, if the parking process can be assisted by a more modern system (system automation), it will be very profitable, both for the industry (automotive industry), parking management companies, parking users and for vehicle owners who have private parking at their homes was studied by irawan [4]. Therefore, a parking system is needed that can make it easier for car drivers to park their car with the Arduino Uno device using an ultrasonic sensor was studied by paidi [5].

Arduino Uno is an open-source single-board micro controller, derived from the Wiring platform, designed to facilitate electronic use in various fields was studied by tian [6]. Its hardware has an Amel Avr processor and the language used is $\mathrm{C}++$ was studied by tromg [7].

An ultrasonic sensor is a sensor that functions to convert physical quantities or sound into electrical quantities and vice versa was studied by jindaprakai [8]. The way this sensor works is based on the principle of the reflection of a sound wave so that it can be used to interpret the existence of an object's distance with a certain frequency was studied by chih [9].

Hotels are companies or business entities that provide lodging services in the form of rooms which are usually complete with eating and drinking facilities and complete facilities and the hotel also has other facilities, namely a parking IoT was studied by muhardi [10]. The car park area at the Citi hotel can accommodate 15 cars in the parking lot was studied by vishnubhotla [11]. Parking is a place where vehicles stop for short or long periods of time. Therefore, researchers took research at the Citi Smart Hotel Pekanbaru in order to provide solutions to parking problems was studied by shao [12].

\section{A. Arduino Uno ATMega $328 P$}

Arduino UNO Atmega 328 is an 8-bit microcontroller chip based on AVR-RISC made by Atmel which has $32 \mathrm{~KB}$ of ISP flash memory with read / write capabilities, $1 \mathrm{~KB}$ EEPROM, 2 KB SRAM was studied by Irawan [13] and because of this $32 \mathrm{~KB}$ Flash memory capacity then this chip is named ATmega328 and the complete features contained in the Arduino UNO module make this module easy to use was studied by atmadja [14], just by connecting the Arduino UNO module with a PC using a USB cable or using a DC-DC adapter was studied by wahyuni [15]. Arduino UNO has 14 input / output pins of which 6 pins can be used as PWM outputs, 6 analog inputs, a $16 \mathrm{MHz}$ crystal oscillator, USB connection, power jack, ICSP head, and reset button was studied by abdel [16].

Arduino UNO has its own advantages compared to other microcontroller boards besides being open source, Arduino also has its own programming language in the form of $\mathrm{C}$ language was studied by fatmawati [17]. In addition, on the Arduino board itself there is a loader in the form of a USB making it easier for us when we program the microcontroller inside the Arduino was studied by park [18]. Whereas on most other Microcontroller boards that still require a separate loader circuit to enter the program when we program the Microcontroller was studied by wahyuni [19]. In addition to the loader when programming, the USB port can also be used as a serial communication port was studied by fonda [20]. Arduino programming language is a $\mathrm{C}$ language that has 
simplified the programming language syntax so that it makes it easier for us to learn and explore Microcontrollers was studied by mendiratta [21].

\section{B. Mp3 Shield}

MP3 Player Shield is an Arduino compatible module that can be used to save audio files to micro SD in a run-of-themill manner was studied by ordila [22]. This shield allows you to play music from micro SD instantly, so you can turn your Arduino into a portable music player or you can add unique tones to your project using this module was studied by Irawan [23]. This module uses VS1053B as an audio decoder chip, which is capable of decoding audio files with Ogg vorbis extensions, MP3, AAC, FLAC, WMA, MIDI, IMA ADPCM, and several other audio formats was studied by wahyuni [24]. This module receives an audio signal input (bitstream) through the SPI interface, then the signal will be decoded by the VS1053B IC and the audio output will be forwarded to the $3.5 \mathrm{~mm}$ audio jack was studied by kanteti [25].

\section{Ultrasonic Sensor HC-SRO4}

An ultrasonic sensor is a sensor that functions to convert physical quantities (sound) into electrical quantities and vice versa. The way this sensor works is based on the principle of the reflection of a sound wave so that it can be used to interpret the existence (distance) of an object with a certain frequency was studied by lee [26]. It is called an ultrasonic sensor because this sensor uses ultrasonic waves (ultrasonic sound). Ultrasonic waves are sound waves that have a very high frequency of $20,000 \mathrm{~Hz}$. Ultrasonic sound cannot be heard by human ears. Ultrasonic sound can propagate through solids, liquids and gases. The reflectivity of ultrasonic sound on the surface of a solid is almost the same as the reflectivity of ultrasonic sound on the surface of a liquid. However, the ultrasonic sound waves will be absorbed by textiles and foam.

\section{METHODS}

The control system development method is a method used to design and evaluate the system that has been designed. The development method used is the prototype method. This method begins with designing a system based on user needs, after which the process of writing and planting the system is carried out on the microcontroller. The implementation stage is combined with the evaluation stage, because when there is an error in the system, repairs are made immediately.

\section{A. System Design}

This stage produces the hardware design that will be used. Development, which initially stood alone, began to be combined with other electronic materials to form an electronic circuit or hardware that could be used in research.

\section{B. 2. Writing and Embed Systems}

After the design of the tool has been completed, a program or source code for the microcontroller is created as a controller for other electronic devices. At this stage the program is written on the Arduino IDE for the designed parking distance control microcontroller.
At this stage, the prototype of the system is tested with a prototype using a simulation of a parking lot and a toy car. And ultrasonic sensor testing is carried out using the black box method to find incorrect or missing function errors.

\section{IMPLEMENTATION}

\section{A. Hardware Design (Hardware)}

Arduino Microcontroller Circuit with Ultrasonic Sensor is shown in Figure 1. Arduino Microcontroller with Speaker is shown in Figure 2. The entire range of hardware configurations is shown in Figure 3.

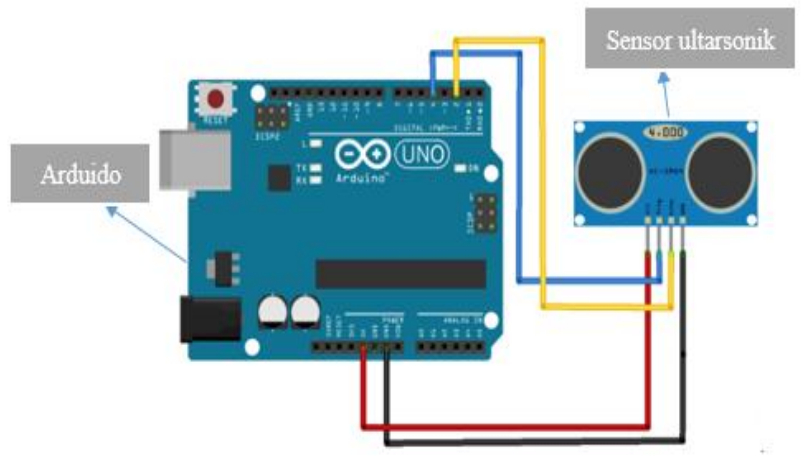

Fig. 1 Arduino Microcontroller Circuit with Ultrasonic Sensor

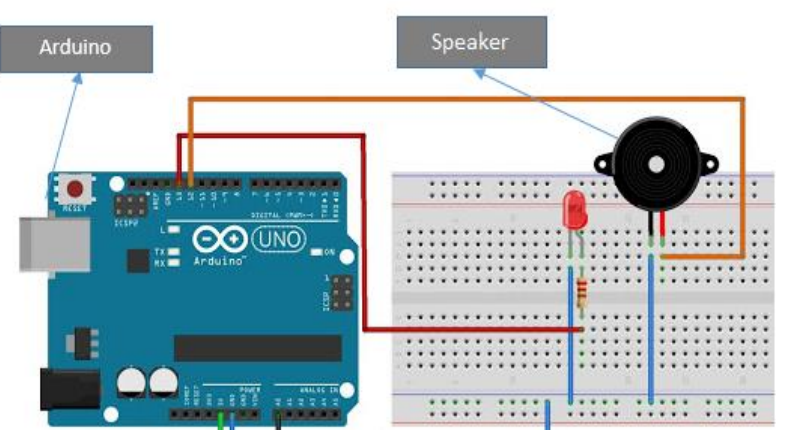

Fig. 2 Arduino Microcontroller Circuit with Speaker.

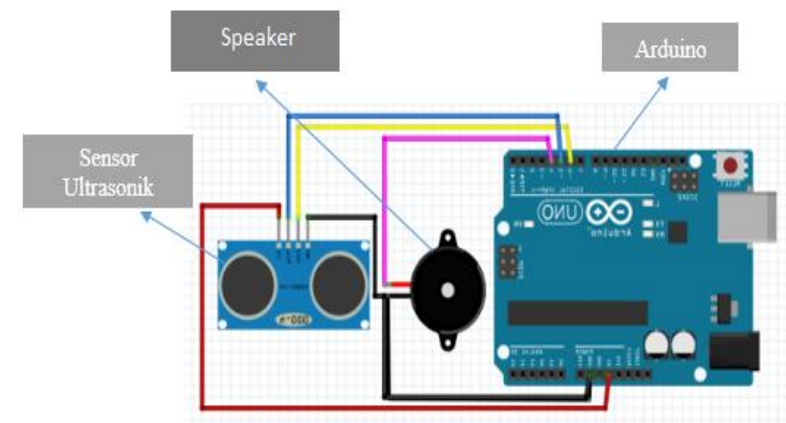

Figure 3 The overall series of hardware configurations

B. Implementation of a Car Parking Distance Controller The car parking implementation is shown in Figure 4.

\section{Implementation}




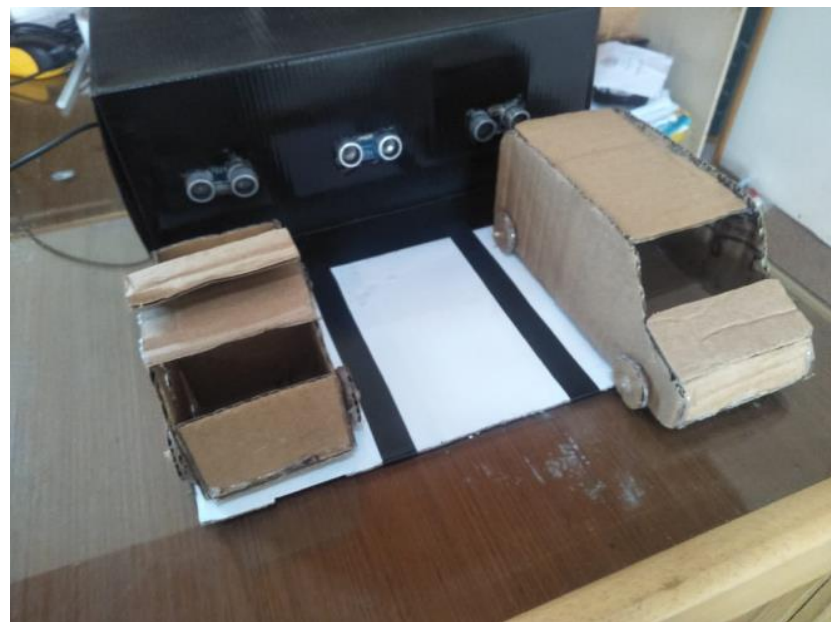

Fig. 4 Implementation of a Car Parking Distance Controller

\section{Testing Systems on the Prototype}

This test uses the BlackBox Testing method, where this test focuses on the functional requirements of the device with the aim of trying to find errors, the error in question is a malfunction, data structure error, or performance error. The result is shown in Table I.

TABLE I. TESTING THE SYSTEM USING BLACKBOX TESTING

\begin{tabular}{|c|l|l|c|}
\hline No & \multicolumn{1}{|c|}{ Procedure } & Expected results & Validation \\
\hline 1 & $\begin{array}{l}\text { If the car approaches the } \\
\text { sensor with a distance of } \\
5 \mathrm{~cm}\end{array}$ & $\begin{array}{l}\text { Then the sound } \\
\text { output emits a } \\
\text { reverse sound }\end{array}$ & Valid \\
\hline 2 & $\begin{array}{l}\text { If the car approaches the } \\
\text { sensor exactly } 2 \mathrm{~cm}\end{array}$ & $\begin{array}{l}\text { Then the sound } \\
\text { output emits a stop } \\
\text { sound }\end{array}$ & Valid \\
\hline 3 & $\begin{array}{l}\text { If the car approaches the } \\
\text { sensor less than } 2 \mathrm{~cm} \\
\text { away }\end{array}$ & $\begin{array}{l}\text { Then the sound } \\
\text { output emits a } \\
\text { forward sound }\end{array}$ & Valid \\
\hline
\end{tabular}

\section{Ultrasonic Sensor Testing at a Distance of $15 \mathrm{~cm}$}

Testing using a toy car on the prototype. So when the ultrasonic sensor detects the car in front of it with a distance of $15 \mathrm{~cm}$, the ultrasonic sensor will output a reverse sound. The result is shown in Figure 5 and Figure 6.

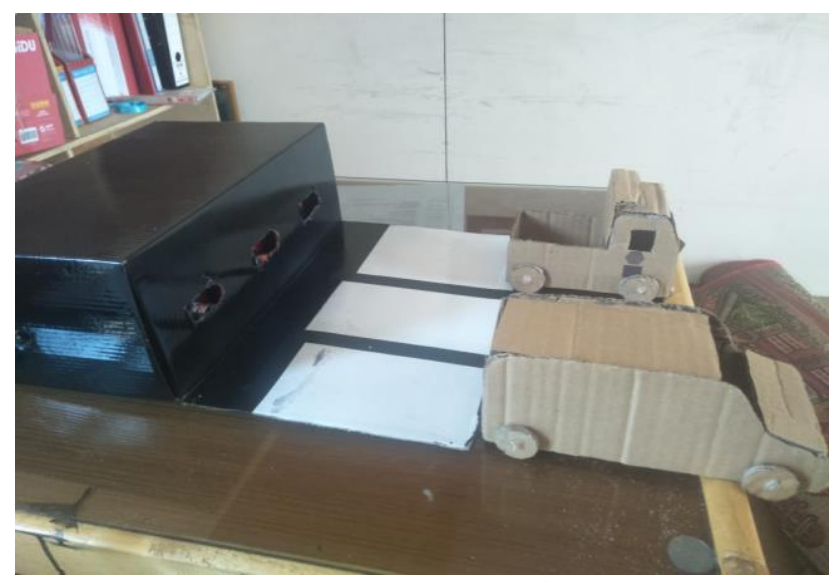

Fig. 5 Ultrasonic Sensor Testing at a Distance of $15 \mathrm{~cm}$

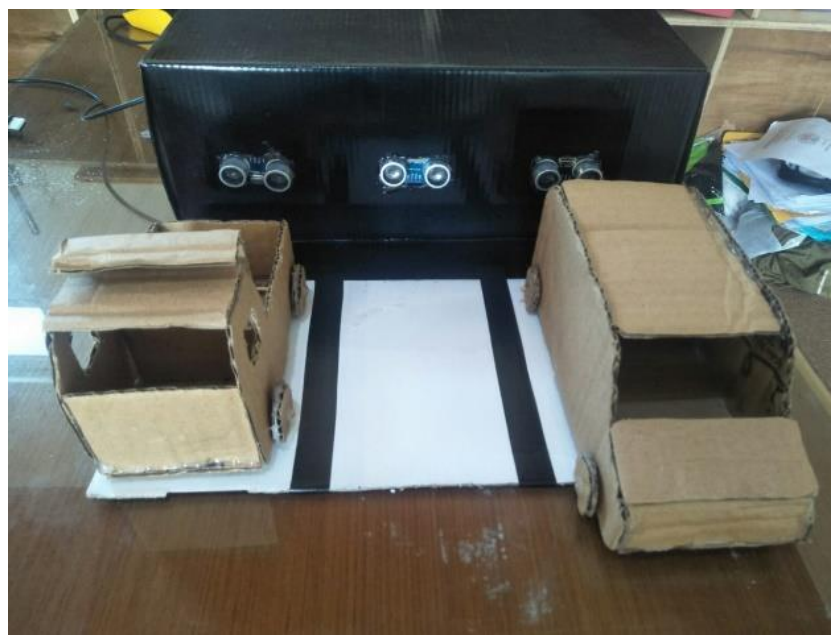

Fig. 6 Ultrasonic Sensor Testing at a Distance of $3 \mathrm{~cm}$

\section{E. Ultrasonic Sensor Testing at a Distance of $2 \mathrm{~cm}$}

Testing using a toy car on the prototype. So when the ultrasonic sensor detects the car in front of it with a distance of $2 \mathrm{~cm}$, the Ultrasonic Sensor will issue sound output in the future. The result is shown in Figure 7.

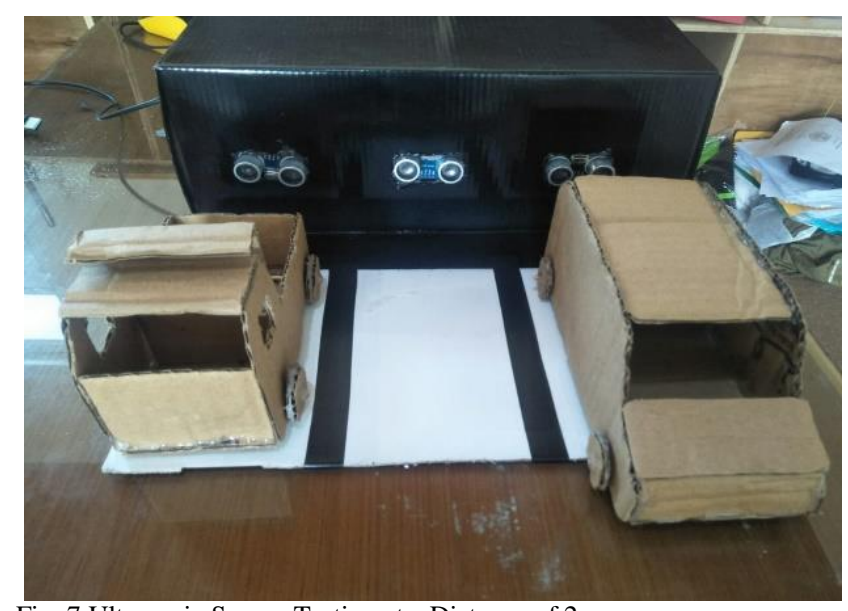

Fig. 7 Ultrasonic Sensor Testing at a Distance of $2 \mathrm{~cm}$

\section{CONCLUSION}

Based on the results of the analysis, design and implementation that has been done. So some conclusions can be drawn including the following: The design of this parking distance control system can carry out commands via the voice issued by the speaker so that it is easier to park the car. With the construction of this parking distance control system, it can make it easier for visitors to the Citi Smart Pekanbaru hotel to park their cars. Based on the results of testing the parking sensor, there is a difference in sensor distance in prototype testing with real testing.

\section{REFERENCES}

[1] T. H. Nasution, A. Wahyudi, K. Asadi and C. Fitriawan, "Designing a car parking helper system in a garage using STM32," 2019 3rd International Conference on Electrical, Telecommunication and Computer Engineering (ELTICOM), Medan, Indonesia, 2019, pp. 9092, doi: 10.1109/ELTICOM47379.2019.8943919.

[2] A. Sahfutri et al., "Smart Parking Using Wireless Sensor Network System," 2018 International Conference on Electrical Engineering and Computer Science (ICECOS), Pangkal Pinang, 2018, pp. 117122, doi: 10.1109/ICECOS.2018.8605241. 
[3] T. Wu, P. Tsai, N. Hu and J. Chen, "Research and implementation of auto parking system based on ultrasonic sensors," 2016 International Conference on Advanced Materials for Science and Engineering (ICAMSE), Tainan, 2016, pp. 643-645, doi: 10.1109/ICAMSE.2016.7840267.

[4] Irawan, Y., Fernando, Y., \& Wahyuni, R. Detecting Heart Rate Using Pulse Sensor As Alternative Knowing Heart Condition. Journal of Applied Engineering and Technological Science (JAETS),2019, 1(1), pp 30-42.

[5] V. Paidi, H. Fleyeh, J. Håkansson and R. G. Nyberg, "Smart parking sensors, technologies and applications for open parking lots: a review," in IET Intelligent Transport Systems, vol. 12, no. 8, pp. 735741, 10 2018, doi: 10.1049/iet-its.2017.0406.

[6] Y. Tian and G. Du, "Infrared Line Following and Ultrasonic Navigating Robot with ATMEGA328 Pro," 2019 IEEE 3rd Advanced Information Management, Communicates, Electronic and Automation Control Conference (IMCEC), Chongqing, China, 2019, pp. 856-860, doi: 10.1109/IMCEC46724.2019.8984181.

[7] Trong-Yen Lee and Chi-Feng Lee, "Microcontroller based automatic parking system," 2012 International Conference on Machine Learning and Cybernetics, Xian, 2012, pp. 875-879, doi: 10.1109/ICMLC.2012.6359468.

[8] N. Jindaprakai and S. Nuchitprasitchai, "Intelligent parking system using multiple sensor detection," 2019 Research, Invention, and Innovation Congress (RI2C), Bangkok, Thailand, 2019, pp. 1-4, doi: 10.1109/RI2C48728.2019.8999966.

[9] Chih-Chiang Cheng, Chia-Yu Lin, Wen-Jong Wu, Kuang-Chong Wu and Chih-Kung Lee, "Highly anisotropic beam patterns for a pot-like ultrasonic sensor with penetrating slots configuration," 2009 IEEE International Ultrasonics Symposium, Rome, 2009, pp. 775-778, doi: 10.1109/ULTSYM.2009.5441488.

[10] Muhardi, Muhardi, et al. "Design Of Web Based LMS (Learning Management System) in SMAN 1 Kampar Kiri Hilir." Journal of Applied Engineering and Technological Science (JAETS) 1.2 (2020): 70-76.

[11] R. Vishnubhotla et al., "ZigBee based multi-level parking vacancy monitoring system," 2010 IEEE International Conference on Electro/Information Technology, Normal, IL, 2010, pp. 1-4, doi: 10.1109/EIT.2010.5612133.

[12] Y. Shao, P. Chen and T. Cao, "A Grid Projection Method Based on Ultrasonic Sensor for Parking Space Detection," IGARSS 2018 - 2018 IEEE International Geoscience and Remote Sensing Symposium, Valencia, 2018, pp. 3378-3381, doi: 10.1109/IGARSS.2018.8519022.

[13] Irawan, Yuda. "Implementation Of Data Mining For Determining Majors Using K-Means Algorithm In Students Of SMA Negeri 1 Pangkalan Kerinci." Journal of Applied Engineering and Technological Science (JAETS) 1.1 (2019): 17-29.

[14] W. Atmadja, J. Yosafat, R. A. Setiawan and I. I. Irendy, "Parking guidance system based on real time operating system," 2014 International Conference on Industrial Automation, Information and
Communications Technology, Bali, 2014, pp. 5-8, doi: 10.1109/IAICT.2014.6922108.

[15] Wahyuni, Refni; Irawan, Yuda. Web-Based Employee Performance Assessment System in PT. Wifiku Indonesia. Journal of Applied Engineering and Technological Science (JAETS), 2020, 1.2: 60-69.

[16] M. F. Abdel-Hafez, A. A. Nabulsi, A. H. Jafari, F. A. Zaabi, M. Sleiman and A. AbuHatab, "A sequential approach for fault detection and identification of vehicles' ultrasonic parking sensors," 2011 Fourth International Conference on Modeling, Simulation and Applied Optimization, Kuala Lumpur, 2011, pp. 1-6, doi: 10.1109/ICMSAO.2011.5775498.

[17] Fatmawati, Kiki, et al. Rancang Bangun Tempat Sampah Pintar Menggunakan Sensor Jarak Berbasis Mikrokontroler Arduino. Riau Journal Of Computer Science, 2020, 6.2: 124-134.

[18] Wan-Joo Park, Byung-Sung Kim, Dong-Eun Seo, Dong-Suk Kim and Kwae-Hi Lee, "Parking space detection using ultrasonic sensor in parking assistance system," 2008 IEEE Intelligent Vehicles Symposium, Eindhoven, 2008, pp. 1039-1044, doi: 10.1109/IVS.2008.4621296.

[19] Wahyuni, Refni; Irawan, Yuda. Web-Based Heart Disease Diagnosis System With Forward Chaining Method (Case Study Of Ibnu Sina Islamic Hospital). Journal Of Applied Engineering And Technological Science (Jaets), 2019, 1.1: 43-50.

[20] Fonda, Hendry. Klasifikasi Batik Riau Dengan Menggunakan Convolutional Neural Networks (Cnn). Jurnal Ilmu Komputer, 2020, 9.1: 7-10.

[21] S. Mendiratta, D. Dey and D. Rani Sona, "Automatic car parking system with visual indicator along with IoT," 2017 International conference on Microelectronic Devices, Circuits and Systems (ICMDCS), Vellore, 2017, pp. 1-3, doi: 10.1109/ICMDCS.2017.8211549.

[22] Ordila, Rian, et al. Penerapan Alat Kendali Kipas Angin Menggunakan Microcontroller Arduino Mega 2560 Dan Sensor Dht22 Berbasis Android. Riau Journal Of Computer Science, 2020, 6.2: 101-106.

[23] Irawan, Yuda. Moving Load Robot Using Wifi Network and Android Based. Journal of Robotics and Control (JRC), 2020, 2.3: 217-220.

[24] Wahyuni, Refni, Et Al. Alat Pengaman Pintu Dengan Password Menggunakan Arduino Uno At Mega 328p Dan Selenoid Door Lock. Informatika, 2020, 12.1: 51-55.

[25] D. Kanteti, D. V. S. Srikar and T. K. Ramesh, "Intelligent smart parking algorithm," 2017 International Conference On Smart Technologies For Smart Nation (SmartTechCon), Bangalore, 2017, pp. 1018-1022, doi: 10.1109/SmartTechCon.2017.8358524.

[26] Y. Lee and S. Chang, "Development of a verification method on ultrasonic-based perpendicular parking assist system," The 18th IEEE International Symposium on Consumer Electronics (ISCE 2014), JeJu Island, 2014, pp. 1-3, doi: 10.1109/ISCE.2014.6884292. 